\title{
A FIATALOK SZABADIDŐSPORTTAL, SPORTMOTIVÁCIÓJÁVAL KAPCSOLATOS KUTATÁSOK TAPASZTALATAIBÓL
}

\author{
Kinczel Antonia - Laoues-Czimbalmos Nóra - Müller Anetta
}

\section{Összefoglalás}

Az ülö és mozgásszegény életmód terjedésével a sportolási szokásokat és fizikai aktivitásokat vizsgáló kutatások egyre inkább elötérbe kerülnek, melyre sok hazai és nemzetközi kutatás is irányul. A szabadidös tevékenységek közül a passziv rekreációs szokások - mint a tv-nézés, zenehallgatás vagy az online térben zajló különbözö tevékenységek - elötérbe kerülnek. Ugyanakkor megfigyelhetjük azt is, hogy az egészségtudatos életmód terjedésével az egészségtudatos fogyasztók a szabadidös sport iránt keresletet támasztanak. Így napjainkban, a sportmotivációban az egészségmegörzés egyre fokozottabb szerepet kap. Módszer: A román és magyar fiatal felnöttek körében kérdöives kutatást szerveztünk a sportolási szokások és a sportmotiváció körében $(N=612)$. A kérdöiv eredményeit SPSS szoftverrel dolgoztuk fel, az alapstatisztikán felül az összefüggéseket is vizsgáltuk (chi²-próba), melyeket grafikus módon is ábrázoltunk. Az eredmények azt támasztják alá, hogy a fiatal felnöttek körében igen sokan végeznek szabadidös sporttevékenységet valamilyen rendszerességgel (75,5\%). Amikor összehasonlitottuk a magyar és román válaszadók sportmotivációs eredményeit, szignifikáns eltérést kaptunk, az egészség, a külsö megjelenés, a boldogság, az önmegvalósitás és a szórakoztató tevékenység tekintetében, amelyek a magyar válaszadók esetében rendre fontosabbak voltak a sportolásra való motivációban, mint a román fiatalok esetében $(p<0,05)$. A motivációkutatások segithetnek bennünket abban is, hogy a fiatalokat hogyan szólitsuk meg, milyen üzeneteket küldjünk annak érdekében, hogy bevonjuk öket, és motiváljuk öket a szabadidösportban való részvételre.

Kulcsszavak: sportmotiváció, fiatal felnöttek, egészségtudatosság

JEL: $Z 2$ 


\title{
FROM THE EXPERIENCE OF RESEARCH ON YOUNG PEOPLE'S LEISURE SPORTS AND SPORTS MOTIVATION
}

\begin{abstract}
Exploratory research on the prevalence of sedentary and sedentary lifestyles and physical activity is gaining prominence, as do many many dangerous and international studies. Leisure activities help promote advertising, watching TV, listening to music, or bringing various activities to the forefront online. At the same time, we can observe that with the spread of a health-conscious lifestyle, health-conscious consumers support free-spirited athletes. Thus, nowadays, health preservation is playing an increasingly important role in a sports motivation. Method: An organization organizing a questionnaire survey among Romanian and Hungarian young adults on sports habits and sports motivation ( $N=$ 612). In order to establish the questionnaire, we should process it with the SPSS software, in addition to the basic statistics, connect it to the examined chi2 test application, which is represented graphically. Results: The results show that they are supported and thus become very long among a young adult with the required regularity of the ultimate regular leisure sports activity (75.5\%). The best choices are the motivational effectiveness of the Hungarian and Romanian respondents, the promotion of health and appearance, happiness, self-observation and the motivation of fun activities, the attention of the Hungarian respondents to launching a sports-capable motivation as a Romanian youth question ( $p$ $<0.05)$. Motivational research allows young people to become more and more aware that a new person is drawing attention to the need to use a new engine.
\end{abstract}

Keywords: sports motivation, young adults, health awareness

JEL: $Z 2$ 


\section{Bevezetés}

A mozgásszegény életmód terjedéséből kifolyólag számos olyan hazai és nemzetközi tanulmány jelent meg, amelyek a fizikai aktivitásnak és szabadidősportnak a szervezetre gyakorolt pozitív hatásait elemzik, vagy felhívják a figyelmet arra, hogy a rendszeres sportolás csökkenti bizonyos betegségek kialakulásának kockázatát (Petruzzello, 1991; Apor, 2011; Salbe et al., 2002; Juhász et al., 2015; Twisk et al., 2002; Müller-Bácsné, 2018; Simon et al., 2018; Pluhár et al., 2003; Bíró, 2015; Dobay et al., 2017; Molnár, 2019, Bendíková et al., 2018). Az életmódelemek között sok kutatás vizsgálja a stressz hatását az emberi szervezetre (Dajnoki et al., 2018; Héder et al., 2018) és a stresszoldó módszerekkel (Bíró et al. 2019; Csörgő et al., 2013) vagy a sportolás stresszoldó hatására (Bodolai et al., 2016) is több kutatás fókuszál.

Napjainkban növekszik az úgynevezett életmódfüggő betegségek (mint a stroke, stressz, obesitas, magas vérnyomás, szívbetegségek) kialakulása és elterjedése, amelyeknek kialakulását a szabadidősport és a fizikai aktivitás növelésével csökkenteni tudnánk (Bujdosó-Dávid, 2015, Ding et al., 2017; Apor, 2011; Iski-Rurik, 2014). Aktív testmozgással, rendszeres szabadidős sport végzésével csökkenteni lehetne több betegség későbbi kialakulását. A sporthoz, a szabadidő hasznos és aktív eltöltéséhez való pozitív hozzáállást, attitüdöt pedig egyre fiatalabb életkorban kell elkezdeni (Bíró, 2018). A felnövekvő nemzedék alakuló identitása miatt fontos a folyamatos szemléletformálás már fiatal kortól kezdve, amely megalapozza számukra az egészségtudatos életmódot. Vizsgálatok igazolják, hogy már fiatal kortól kezdve (Boda et al., 2016) egészen idős korig (Juhász et al., 2015; Kopkáné et al., 2015) lényeges és hatékony az egészségmagatartás formálása (Bujdosó-Remenyik, 2008, Hidvégi et al., 2015). Sajnos mai napig rengetegen halnak meg Magyarországon, de Európában is a szív- és érrendszeri megbetegedésekben, daganatos megbetegedésekben, korai koszorúér-megbetegedésben, öngyilkosságban, amire megoldás lenne az, ha a lakosság egyre nagyobb aránya sportolna szabadidejében. Éppen ezért is fontos a lakosság szabadidőkutatása különböző generációk, családok esetében, hogy ezen kutatások eredményeire alapozva tehessünk javaslatokat. A sport számos pozitívuma ellenére igen sok szabadidős kutatás igazolja azt, hogy a passzív rekreációs tevékenységek dominálnak a különböző célcsoportokon végzett kutatásokban is (Mosonyi et al., 2013; Czabai et al., 2007; Horkay et al., 2018a). A sportolási szokásokat vizsgálta egyetemi hallgatók és a lakosság körében több kutatás is (Kosztin-Balatoni 2020; Murányi, 2010; Mosonyi et al., 2013; Kith et al., 2014, 2017; Fenyves et al., 2019). Ezek azt mutatják, hogy a gyermekeket a telefon, internet világa egy idő után annyira leláncolja, hogy egyre kevesebb időt töltenek a szabadban, kevesebbet mozognak, ugyanakkor a személyiségük is negatív irányba változhat. A lakosság körében a passzív szabadidős tevékenységek dominálnak, és még mindig alacsony a szabadidősportot 
rendszeresen üző magyarok aránya. A szabadidős trendeket bemutató kutatások a szabadidős fogyasztást befolyásoló tényezőket, motivációkat és aktivitásokat elemzik (Gödény et al., 2018; Molnár, 2019; Horkai et al., 2018b; Lenténé et al. 2019a, b; Fenyves et al, 2018; Lengyel, 2019, Gősi et al., 2019; Boda et al., 2019; Bácsné et al., 2018a). Ezek a trendkutatások is igazolják az egészségtudatos magatartás erősödését, azaz a sport vagy szabadidő-eltöltés vagy akár a turizmus motivációjában az egészség megőrzése dominánsan megjelenik. Igen népszerűek azok a szabadidős tevékenységek is, amelyek az önmaguk határainak feszegetését, az élményeket és a szórakozást helyezik elötérbe (Boda, 2018), melyek különösen a fiatal felnőttek motivációjában erősödnek fel napjainkban.

A motiváció az emberek viselkedésének a hátterét jelentő pszichológiai folyamat (Gage-Berliner, 1991; Nagy, 2000), amely a szabadidős sportolás cselekvését is befolyásolja, és a mozgatója annak, hogy az egyén milyen sportot vagy sportszínteret választ. A motiváció ugyanakkor meghatározza azt is, hogy a sportolásban az egyén mennyire aktívan vesz részt (aktív és passzív sportfogyasztás). Az emberekre hatással bíró belső késztetés eredete többféle lehet, melyeket a szakirodalmak megkülönböztetnek. Ezeket szükségletnek definiálhatjuk, vannak olyan ingerek, amelyek eredete biológiai motívumokból áll (oxigénhiány, éhség stb.), és vannak olyanok, amelyek pszichológiai eredetűek, azaz belső késztetésből fakadó drive-ok. Ezek a drive-ok pszichés hajtóerőként jelennek meg, és például a szervezet konzisztenciájának és belső egyensúlyának megteremtésére szolgálnak. Megkülönböztetünk „intrinsic” (önjutalmazó) és „extrinsic” motivációkat. Az első, amelyben a cselekvés ingere maga a cselekvésből fakadó élvezet. A másik motiváció az „extrinsic” (eszköz jellegü külső késztetés) vagy úgynevezett teljesítménymotiváció, amelyben a személy késztetése valamilyen cél elérése érdekében történik (például a szegénységből való kitörés, a sportban a fittség növelése vagy a prevenció megvalósítása), illetve külső tényező hatására (Lenténé, 2017; Lenténé, 2014). Az élet és a sport területén ezek a motivációk különféle formában jelenhetnek meg.

Nagyon fontos a sporthoz a megfelelő motiváció jelenléte (Fyodorov et al., 2019; Bendíková-Dobay, 2017). Sokan amiatt nem sportolnak, mivel motiválatlanok. Megkérdeztük a válaszadókat, hogy őket ki motiválta arra, hogy elkezdjenek sportolni. 518 fő saját elhatározásából kezdett el sportolni. A barátok 176 föt buzdítottak a sportra, míg a szülők 148 föt. Testvér, tanár, edző, orvos kevés embert motivált a sportra. Növelni kellene azt, hogy a szülők motiválják a gyerekeket a sportra, hiszen a család vagy szülő meghatározó szerepéről több kutatás ír (Laoues, 2017; MezőMező, 2017; Herpainé, 2018; Kőnig-Görögh, 2019). Minél több szülő végezne aktív testmozgást, annál több gyermek is bekapcsolódna a sport világába.

Több kutatás is megerősítette (Kibédi-Hidegh, 2020), hogy a médiának vagy a celebeknek is igen meghatározó a szerepe a befolyásolásban vagy akár a motiváció kialakításában, megerősítésében. 
Amennyiben növelni tudjuk az emberek aktív testmozgását, megfelelő motivációt nyújtunk nekik, akkor prevenciót tudunk megvalósítani az életmódfüggő betegségekkel szemben.

\section{Anyag és módszer}

A szabadidő-eltöltés vizsgálatára, a motiváció jelenlétére kérdőíves kutatást terveztünk, amelyben a vizsgálatban résztvevő személyek szabadidős preferenciarendszerére, motivációs eszközeire voltunk kíváncsiak. A rekreációs szokások területén az aktív és passzív tevékenységi formák gyakoriságát is vizsgáltuk, továbbá azt, hogy milyen pozitív változást éreztek sport után. Rákérdeztünk arra is, hogyan viszonyulnának ahhoz, ha a munkahelyen/iskolában/egyetemen több lenne a sportolási lehetöség, milyen előadáson vennének szívesen részt, kik jelentenek számukra motivációs tényezőt.

A válaszadók 65\%-a (398fö) nő, 35\%-a (214fó) pedig férfi. 64,4\%-uk (394fö) Magyarországon él, 35,6\%-uk (218 fó) pedig Romániában.

Az 1. ábra mutatja a kitöltők életkori megoszlását, melyből kiderül, hogy a válaszadók 76\%-a (464 fó) a 19-35 éves korosztályba tartozik. Így a kutatásunk eredményei jól szemléltetik a fiatalok (egyetemisták, fiatal munkavállalók) szabadidős és sportolási szokásait, sportmotivációját.

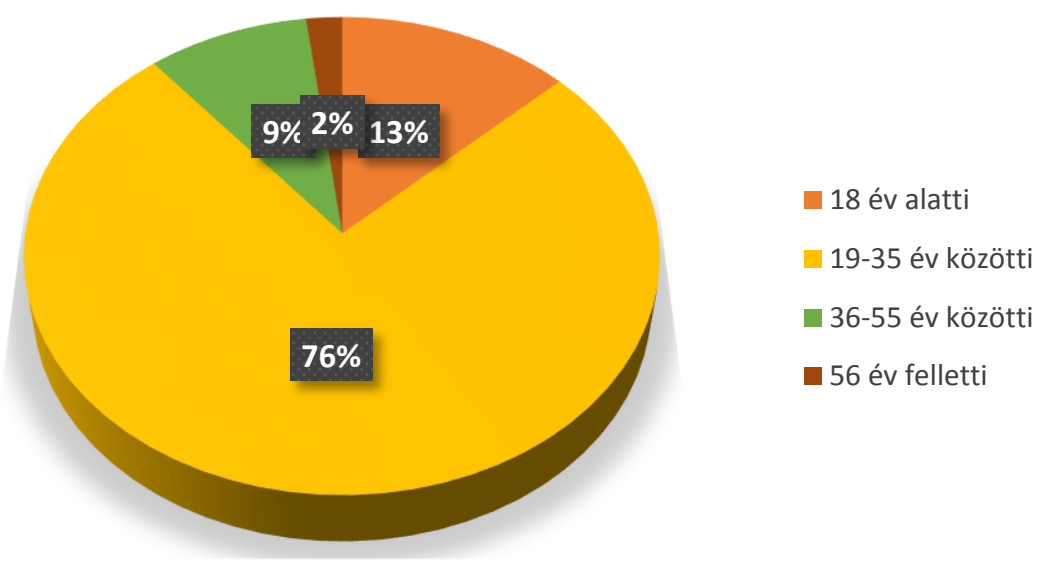

1. ábra. A minta életkori bontása

Forrás: Saját kutatás, saját szerkesztés

A minta munkaerőpiaci státuszát és a munkavégzés jellegét a 2. ábra mutatja. A válaszadók 71\%-a tanuló, akikre az ülő életmód dominánsan jellemző, hiszen igen magas a tanulással eltöltött idő. Az ülőmunkát végzők aránya $10 \%$ a mintában, és a 
fizikai munkavégzés csupán 6\%-ra jellemző. A vegyes, azaz ülőmunka és fizikai munka keveréke a mintánkban lévők 13\%-ára igaz. A munkavégzés jellege nagyban befolyásolhatja a szabadidős tevékenységeket és a sportolási szokásokat. Mivel a tanulókra és az ülő munkát végzőkre igaz a nagyon magas ülőidő, vagyis inaktivitás, ezért az egészségtudatos fogyasztók a szabadidejükben tudják kompenzálni részben az inaktivitást.

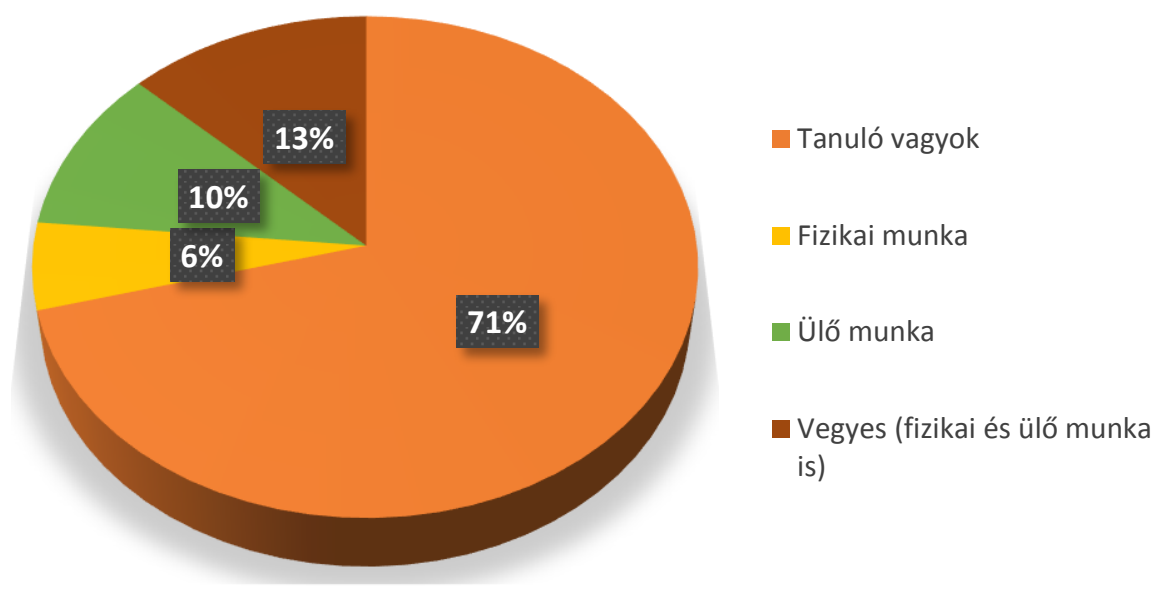

2. ábra. A minta munkaerőpiaci státusza és a munkavégzés jellege szerinti megoszlása

Forrás: Saját kutatás, saját szerkesztés

A lakóhely típusa meghatározó lehet a sportolás és a fizikai aktivitás alakulásában. Bergier és munkatársai (2016) azt igazolták egy IPAQ-vizsgálatban $(\mathrm{N}=646)$, hogy azok a fiatalok, akik családi házban éltek vagy olyan városrészben ahol családi házak voltak, azok szignifikánsan sokkal több fizikai aktivitást végeztek, mint azok a fiatalok, akik bérházakban vagy társasházban laktak. A kitöltőink 41,30\%-a városon él, 30,60\%-a falun, 24,30\%-a megyeszékhelyen és 3,80\%-a pedig fóvárosban (3. ábra). 


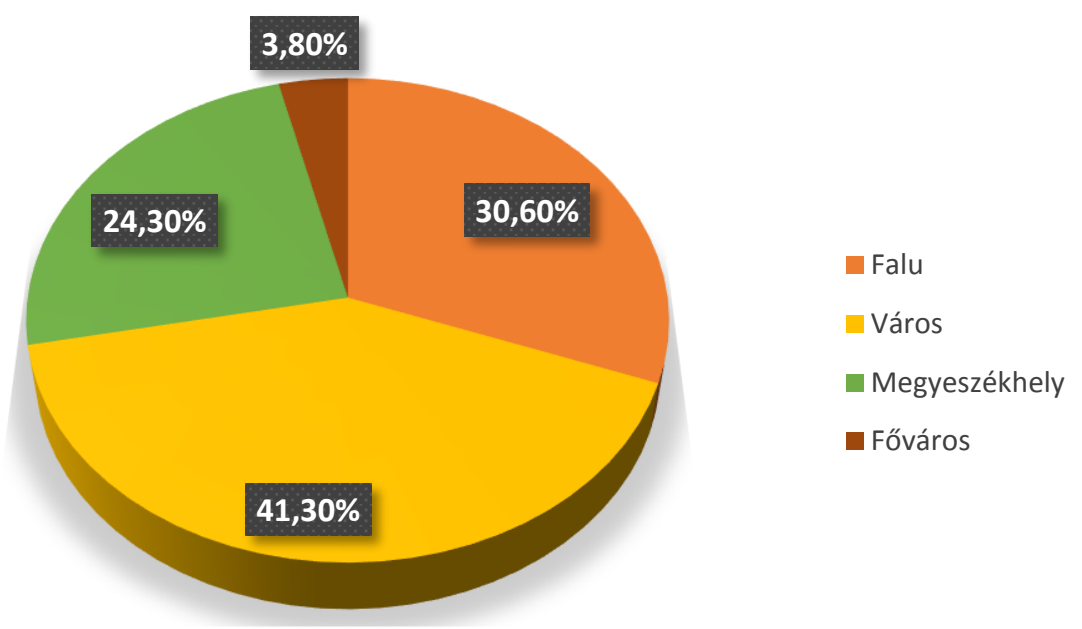

3. ábra. A minta lakóhely szerinti megoszlása

Forrás: Saját kutatás, saját szerkesztés

A legtöbben még mindig a passzív szabadidős tevékenységekkel töltik el szabadidejüket. Nagyon népszerű a média világa, amit bizonyít a kutatásunk is, hiszen a válaszadók 67,5\%-a a szabadidejét internetezéssel (számítógép, mobil, tablet) tölti. A második legnépszerübb időtöltés is a passzív pihenéshez tartozik, hiszen 62,7\%-a a válaszadóknak tv-nézéssel vagy zenehallgatással próbálja kipihenni a fáradalmakat, és próbálnak újra feltöltődni. Ezek után jön be az aktív szabadidő-eltöltés, 49,5\%-a a válaszadóknak a szabadidejében sportol. 46,9\%-a az embereknek szereti passzív pihenéssel, lustálkodással az ágyban eltölteni az idejét. A kutatás egybevág más hazai kutatási eredményekkel, ahol a fiatal felnőttek mintájában szintén a passzív szabadidős tevékenységek domináltak (Müller et al., 2011; Mosonyi et al., 2013; Boda et al., 2015; Boda et al., 2019; Laoues et al., 2019). Népszerű szabadidő-eltöltés még az olvasás vagy meditáció 40,7\%, a házimunka (takarítás, főzés, mosás, kukaürítés, kertészkedés stb.) 38,2\%, háziállattal való sétálás, játszás 32,2\%, a tanulás $25,5 \%$, a vásárlás $22,9 \%$, míg kevésbé népszerủ a sporteseményeken való részvétel szurkolóként 20,9\%, a vallásos tevékenységek (templomba járás, egyházmegyei programokon való részvétel, hittanóra stb.) 16,8\%, egészségmegőrzés (szauna, fürdő) 13,2\%, muzsikálás 8,8\%, horgászat 5,7\%, vadászat 1,3\%. A meditáció és spiritualitás felértékelődését és keresletének növekedését erősíti meg több kutatás (Lengyel, 2016, 2019). A válaszadók nem mindig ugyanazokat a szabadidős tevékenységeket végzik, több választ is jelölhettek, ezért jöttek ki ezek a százalékos arányok. Ezekből a számadatokból elmondható, hogy bár az emberek 81,5\%-a ülőmunkát végez vagy mindkettőt 
(ülő és fizikai munkát is), mégis kevés időt töltenek aktívabb szabadidős tevékenységekkel. Érthető, hogy aki fizikai munkát végez, az szabadidejében inkább olvas, pihen, zenét hallgat.

\section{Eszközök}

A válaszadók a kérdőívet online formában töltötték ki, a válaszadás önkéntes volt ( $\mathrm{N}$ = 612). Az adatokat SPSS segítségével dolgoztuk fel.

\section{Eredmények}

\section{Sportolás}

A kitöltők 68,3\%-a végez testnevelés órán kívüli tevékenységet, melynek hossza minimum fél óra. Ez az érték jobb, mint amit a hazai mért adatokról korábban publikált az Eurobarométer 2018-as tanulmánya, mely szerint az Unióban a lakosságnak csupán 7\%a sportolt heti ötször vagy annál többször, 33\%-uk heti 1-4 alkalommal, míg az ennél ritkábban sportolók aránya $14 \%$ volt. 46\%-os volt azoknak a felnőtteknek az aránya, akik soha nem végeznek rendszeres sporttevékenységet (Eurobarometer, 2018). A válaszadók 30,7\%-a sportol heti öt vagy annál több alkalommal, ami az uniós lakosság értékeihez képest nagyon jó eredmény. Szintén elmondható, hogy a kitöltők 24,5\%-a az, aki nem sportol, néha sétál, kerékpározik, szóval maximum egy órát tesz ki összesen a sportolása, de ez az eredmény is jobb a 2018-as Eurobarometer eredményeihez képest.

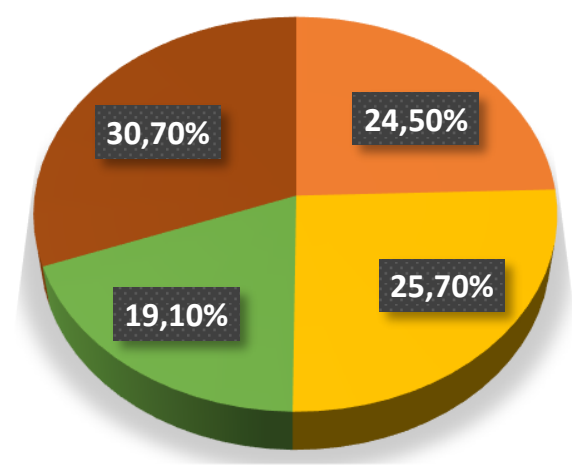

Nem sportolok. Néha sétálok, kerékpározok, szóval maximum 1 órát

Hetente 2-3 alkalommal sportolok

4. ábra. A minta sportolásának, annak gyakoriságának alakulása

Hetente 3-5 alkalommal sportolok

\section{Forrás: Saját kutatás, saját szerkesztés}




\section{Sportmotiváció}

A kutatásunk eredménye szerint a válaszadók leginkább azért szoktak sportolni, hogy fenntartsák az egészségüket és a jó közérzetüket (átlag = 5,6), ugyanakkor a sport mint boldogságforrás is elég markánsan megjelenő motiváció a sportolásban (átlag = 5,3). A külső megjelenés, az esztétikus külalak is sok fiatalt motivál arra, hogy elkezdje vagy folytassa a szabadidősportot (átlag $=5,1$ ).

\section{A sportmotiváció átlagértékei}

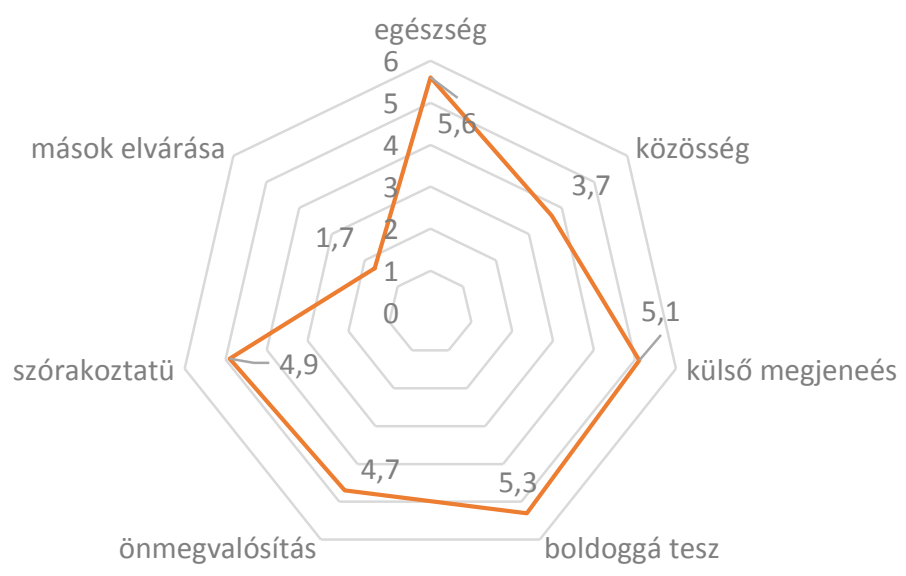

5. ábra: A sportmotiváció átlagértékeinek alakulása a vizsgált mintában az 1-7-es Likert-skála alapján ( 1 = egyáltalán nem jellemző, 7 = teljes mértékben jellemző) Forrás: Saját kutatás, saját szerkesztés

A sportmotiváció alakulása a román és a magyar mintában az összefüggésvizsgálat tapasztalatai alapján

A magyarok sportolási aktivitása magasabb volt, mint a románoké, mivel a magyar válaszadók 71,6\%-a (282fó), míg a románok 62,4\%-a (136fó) nyilatkozta azt, hogy sportol (amely alatt a minimum heti egy alkalommal végzett és legalább 30 percnyi szabadidős sportolást értettünk). A magyarok nagyobb sportolási aktivitását a chi ${ }^{2}$ próba igazolta $(\mathrm{p}<0,05)$.

A sportolási gyakoriság tekintetében is szignifikáns különbséget tapasztaltunk a román és a magyar válaszadók között $(\mathrm{p}<0,05)$. A magyarok között többen vannak 
azok, akik akár 2-5 órát sportolnak, és kevesebben vannak a románokhoz képest, akik nem sportolnak.

Az egészség mint sportmotiváció a magyarok esetében erősebb motiváció, mint a román válaszadóknál, hiszen a magyarok 69,8\%-a volt, aki 7-est és 6-ost adott erre, vagyis nagyon jellemző és teljes mértékben jellemző rá, míg a románoknak csupán 55\%-a értékelte ezt 6-ossal vagy 7-essel a Likert-skálán $(\mathrm{p}<0,05)$. Az eredmény igen erős szignifikáns eltérést mutat a nemzetiségek tekintetében. Hazai kutatások, melyek a fiatal felnőttek mintáján mutatják be a sportmotivációt, hasonló eredményeket mutatnak, és megerősítik az egészségorientált szabadidősportot, amely erős motiváció a fiatalok esetében (Mosonyi et al., 2013). Laoues és munkatársai (2019) megerősítették, hogy a 8-18 éves, fogyatékkal élő fiatalok szabadidősport-motivációjában is az egészség a domináló, majd a külalak és a társaság, szórakozás.

A külső megjelenés, fogyás motivációja a szabadidős sportban szintén inkább a magyarokra jellemző, hiszen a magyarok 59,9\%-a 6-osra és 7-esre értékelte, míg a román válaszadóknak csupán 43,1\%-a jelölte a 6 -os és 7 -es értéket $(\mathrm{p}<0,05)$.

A sport mint boldogságtényező szintén a magyar válaszadók értékrendjében jelenik meg dominánsabban, hiszen a magyarok 63\%-a 6-os és 7-es értéket választott, míg a románoknak csupán $47,4 \%$-a értékelte hasonlóan fontosnak ezt a motivációs tényezőt $(\mathrm{p}<0,05)$.

Az a motiváció, hogy megismerhetem önmagam és határaimat is, szintén inkább a magyarok sportmotivációjában jelenik meg erőteljesebben, hiszen a magyar válaszadók között rendre többen voltak azok, akik 5-ösre, 6-osra és 7-esre értékelték ezt a motivációt a sportolásban $(\mathrm{p}<0,05)$.

Az izgalmas szórakoztató tevékenység mint motiváció a szabadidősportban szintén a magyar válaszadók esetében sokkal erősebb, hiszen míg a magyarok 52,8\%-a értékelte 6-osra és 7-esre, addig a román válaszadóknak 39,9\%-a értékelte 6-osra és 7-esre ezt a motivációt $(\mathrm{p}<0,05)$.

Az együtt lenni másokkal, vagyis a közösség mint motivációs faktorban és a mások elvárásának sportolást motiváló szerepében a román és magyar válaszadók eredményeiben nem tudtunk különbséget igazolni.

\section{Konklúziók}

A kutatás igazolta, hogy a magyar fiatal felnőttek szabadidősportban való részvételük alapján aktívabbak a román fiataloknál.

Ez a kutatásunk megerősítette az Eurobarométer (2017) felmérés adatait, mely a felnőttek mintáján ugyanezt igazolta. A románok 6\%-a, míg a magyarok 9\%-a az, aki rendszeresen (heti több mint 5 alkalommal) végez szabadidősportot, a románok 
563\%-a, a magyarok 53\%-a az, aki soha nem sportol. Így az eu-s kutatás is a magyarok fokozottabb sportaktivitását mutatta be. A mintában az eredmények azt igazolták, hogy a fiatal felnőttek közel háromnegyede végez szabadidős sportot, ami azt mutatja, hogy a korábbi felmérésekhez képest aktívak a minta válaszadói. Az Eurobarométer (2017) eredményei is azt igazolták, hogy a 19-24 éves korosztály sportol a legtöbbet, majd az életkor előrehaladtával csökken az érték.

Amennyiben a felmérések az idősebb korosztályok eredményeit mutatják be, már csökken a sportolási kedv, és az életkor elörehaladtával növekvő inaktivitással társul. Az egészségfejlesztési programokban az aktív fiatalok, sportolók megtartására kellene a hangsúlyt helyezni.

A szabadidősport motivációjában az egészség, a jó kinézet, a boldogság, önmegvalósítás és a szórakoztató tevékenység miatt sportolnak a fiatal felnőttek. Mind a román, mind a magyar mintában leginkább ezeket a motivációkat értékelték magas átlagpontszámmal a válaszadók, azonban ezek a motivációs tényezők a magyarok válaszaiban dominánsabban jelennek meg, mint a román válaszadók esetében.

Az Eurobarométer (2017) szerint a válaszadók 54\%-a az egészségmegőrzés miatt, majd a 47\%-a fitneszszint növelése miatt, 38-a a relaxáció miatt, 30\%-a a szórakozás miatt és $28 \%$-uk azért sportol, hogy javítsák a fizikai teljesítőképességüket. Tehát az uniós felmérés is az egészségtudatosság erősödését jelzi a sportmotivációban.

Ezek a motivációk fontosak lehetnek a célcsoporthoz eljuttatott üzenetekben, hiszen ezek a hívószavak segíthetnek a célcsoport aktivitásának növelésében és a célcsoport megtartásában.

\section{Köszönetnyilvánítás}

A publikáció elkészítését a „GINOP-2.3.2-15-2016-00062 Életminőség fejlesztése Kelet-Magyarországon: Táplálkozás-, teljesítménybiológiai és biotechnológiai experimentális kutatások és eszközfejlesztések a humán megbetegedések megelőzésére és kezelésére" projekt támogatta.

\section{Hivatkozott források}

[1.] Apor P. (2011). A cardiovascularis kockázat kapcsolata a fizikai aktivitással és a fittséggel [The connection between cardiovascular risk, physicl activity and fitness]. Orvosi Hetilap, 152. sz. 107-113. o. DOI: 10.1556/OH.2011.29022

[2.] Bácsné Bába É. - Fenyves V. - Dajnoki K. - Szabados, Gy. (2018a): Sportszolgáltatások kínálatának elemzése szervezeti szempontok alapján. International Journal of Engineering and Management Sciences / Müszaki és 
Menedzsment Tudományi Közlemények, 3. évf. 4. sz. 465-474. o. DOI: 10.21791/ijems.2018.4.38.

[3.] Bácsné Bába É. - Fenyves V. - Szabados Gy. - Pető K. - Bács Z. - Dajnoki K. (2018b): Sport Involvement Analysis in Hungary, in the North Great Plain Region. Sustainability, 10. évf. 5. sz. Paper 1629. DOI:10.3390/su10051629.

[4.] Bácsné Bába É. - Pfau C. - Dajnoki K. - Müller A. (2018c): Examining the quality parameters of sports services. In: Šimonek, J. - Dobay, B. (Eds.) Sport science in motion: proceedings from the scientific conference. Športová veda $\mathrm{v}$ pohybe: recenzovaný zborník vedeckých a odborných prác z konferencie. Komárno, Univerzita J. Selyeho, 236-243. p.

[5.] Balogh R. - Dajnoki K. - Bácsné Bába É. (2019): Miért beteg a magyar futball még mindig? - A magyar labdarúgás játékos piacának jellemzése. Jelenkori Társadalmi és Gazdasági Folyamatok, 13. évf. 3-4. sz. 105-117. o

[6.] Bendíková, E. - Dobay, B. (2017): Physical and sport education as a tool for development of a positive attitude toward health and physical activity in adulthood. European Journal of Contemporary Education, Vol. 6. No. 1. 14-21. p. DOI: $10.1556 / \mathrm{OH} .2011 .29022$

[7.] Bendíková, E. - Marko, M. - Müller, A. - Bácsné Bába, É. (2018): Effect of Applied Health-Oriented Exercises in Physical and Sport Education on Musculoskeletal System of Female Students. Acta Facultatis Educationis Physicae Universitatis Comenianae, Vol. 58. No. 2. 84-96. p. DOI: $\underline{10.1556 / \mathrm{OH} .2011 .29022}$

[8.] Bergier, J. - Bergier, B. - Tsos, A. (2016): Place of residence as a factor differentiating physical activity in the life style of Ukrainian students. Ann Agric Environ Med, Vol. 23. No. 4. 549-552. DOI: $\underline{10.5604 / 12321966.1226844}$

[9.] Bíró M. (2018): Bevezetés a sportpedagógiába In: Münnich, Á. (szerk.) Fejezetek a Sport-pszichodiagnosztika és Tanácsadás témaköreiből. Debrecen, Debreceni Egyetem Bölcsészettudományi Kar Pszichológiai Intézet, Paper: http://psycho.unideb.hu/sport/fejezetek/bm_sportpedagogia/_book/index.html

[10.] Bíró M. (2015): A testnevelés aktuális kérdései. In: Révész L. - Csányi T. (szerk.) Tudományos alapok a testnevelés tanításához I. kötet: szemelvények a testnevelés, a testmozgás és az iskolai sport tárgyköréből. Társadalom-, természet- és orvostudományi nézőpontok. Budapest, Magyar Diáksport Szövetség, 105-136. o.

[11.] Bíró, M. - Molnár, A. - Hídvégi, P. - Mikhárdi, S. - Pucsok, J. M. - Lenténé, P. A. (2019): The role of massage in tourism, and the hotels offerings 
in Hungary. Science in motion: Proceedings from the scientific conference. Komárno, Szlovákia, Univerzita J. Selyeho V Komárne, 27-36. p.

[12.] Boda E. J. - Bácsné Bába É. - Laoues-Czimbalmos N. - Müller A. (2019) : Rekreációs fogyasztói szokások vizsgálata magyar fiatal felnőttek körében. Különleges Bánásmód, 5. évf. 4. sz. 33-44. o. DOI: $\underline{10.18458 / K B .2019 .4 .33}$

[13.] Boda, E. (2018): Examination of Adventure park consumers in therm of motivations and amount of leisure time. Acta Oeconomica Universitatis Selye, Vol. 7. No. 2. 33-46. p.

[14.] Boda E. J. - Müller A. - Biró M. - Széles-Kovács Gy. - Nagy Zs. - Ráthonyi-Ódor K. - Lengyelné Hargitai A. - Dobay B. - Hidvégi P. (2016): A study on attitude to health among kindergarten children. In: Bendíková, E. - Mičko, P. (szerk.) Physical Activity, Health and Prevention: International Scientific Conference: Conference Textbook of Invited Lectures. Banská Bystrica, Matej Bel University Faculty of Arts, Department of Physical Education and Sports, 15-24. p.

[15.] Bujdosó Z - Remenyik B. (2008): A hazai turisták életminőségének a feltérképezése az Észak-Magyarország Régióban In: Dávid, L (szerk.) A turizmus szerepe az Észak-Magyarország Régióban I-II Gyöngyös, Károly Róbert Főiskola, 40-48. o.

[16.] Bujdosó, Z. - Dávid, L. (2013): Extreme sports and other activities in tourism with special regard to the Mátra Mountain. Journal of Physical Education and Sport, Vol. 13. No. 1. 39-45. p.

[17.] Hidvégi P. - Bíró M. - Müller A. (2015): A rekreáció elmélete és módszertana 2: Egészségfejlesztés. Eger, Líceum Kiadó, 25 o.

[18.] Juhász I. - Kopkáné Plachy J. - Kiszela K. - Biró M. - Müller A. - Révész L (2015): Időskorúak rekreációs fizikai aktivitásának hatása a kardiorespiratorikus rendszerre. Magyar Sporttudományi Szemle, 16. évf. 63. sz. 4-8. o.

[19.] Kopkáné Plachy J. - Juhász I. - Biró M. - Fodor É. - Révész L. (2015): Egerben élő nyugdíjasok egészségi állapotának és testedzési szokásainak vizsgálata. Acta Academiae Paedagogicae Agriensis Nova Series: Sectio Sport, 42. évf. 27-36. o.

[20.] Boda E. - Honfi L. - Bíró M. - Révész L. - Müller A. (2015): A szabadidő eltöltésének és a rekreációs tevékenységek vizsgálata egri lakosok körében, Acta Academiae Paedagogicae Agriensis Nova Series: Sectio Sport, 42. évf. 49-62. o.

[21.] Bodolai M. - Lívják E. - Boda E. - Bíró M. (2016): A jóga hatása a szervezetre, szerepe a stresszkezelésben. Acta Academiae Paedagogicae Agriensis Nova Series: Sectio Sport, 43. évf. 51-67. o.

[22.] Bujdosó, Z. - Pénzes, J. (2015): Tourism competitiveness and tourism development in the border regions of Hungary. In: Trukhachev, V. (szerk.) 
Sustainable Development of Tourism Market: International Practices and Russian Experience. Stavropol, Oroszország: Stavropol State Agrarian University, 18-26. p.

[23.] Czabai V. - Bíró M. - Hajdu P. (2007): Az Eszterházy Károly Főiskola hallgatóinak életmódja, sportolási szokásai. Az Eszterházy Károly Főiskola tudományos közleményei. Vizsgálatok a sporttudomány és az egészségturizmus területén = Acta Academiae Paedagogicae Agriensis. Sectio Sport, 34 . évf. 29-38. o.

[24.] Csörgő T. - Bíró M. - Kopkáné Plachy J. - Müller A. (2013). Masszázsterápia hatásának vizsgálata hatvan év feletti nők körében. Az Eszterházy Károly Főiskola tudományos közleményei. Tanulmányok a sporttudományok köréből. Testkultúra, sporttudomány = Acta Academiae Agriensis. Sectio Sport, 40. évf. 5-16. o.

[25.] Dajnoki, K (2011): Conflict treatment in the equal employment opportunity human resource management. Acta Scientiarum Socialium, Tom. XXXIII. 77-85. p.

[26.] Dajnoki, K. (2015): Judgement of the Factors Influencing the Integration of the Employees with Disabilities or Reduced Work Capacity into Workplaces. In. The Northern Great Plain Region Annals

[27.] Dajnoki K. - Halász P. - Kőmíves, P. M. - Szabados, Gy. - Bácsné Bába, É. (2019): Airsoft kilátások: sport és a szervezeti oldal. Hadtudomány, 29. évf. E-szám 105-115. o. DOI: 10.17047/HADTUD.2019.29. E.105

[28.] Dajnoki, K. - Szabados, Gy. N. - Bácsné Bába, É. (2018): A Case Study on Human Resource Management Practice of a Sport Organization. International Journal of Engineering and Management Sciences, Vol. 3. No. 4. 410-425. o. DOI: $10.21791 /$ IJEMS.2018.4.34.

[29.] Ding, D. - Kolbe-Alexander, T. - Nguyen, B. et al. (2017): The economic burden of physical inactivity: a systematic review and critical appraisal. Br J Sports Med. Vol. 51. No. 1. 392-1409. p.

DOI: $10.1136 /$ bjsports-2016-097385

[30.] Dobay, B. - Müller, A. - Bendíková, E. (2017): Adult Health in Terms of Selected Lifestyle Factor. Disputationes Scientificae Universitatis Chatholicae in Ruzomberok, Vol. 17. No. 4. 32-39. p.

[31.] Eurobarométer (2017): Special Eurobarometer 472, Sport and physical activity

[32.] Eurobarometer (2018): Special Eurobarometer 472, Sport and physical activity, https://www.loketgezondleven.nl/sites/default/files/2018 12/Eurobarometer_472_PhysActivSports2018.pdf 
[33.] Fenyves, V. - Dajnoki, K. - Bácsné Bába, É. (2018): Assessment of sport activites among higher education students in Eastern Europe. Sea: Practical Application of Science, Vol. 6. No. 3. 347-353. p.

[34.] Fenyves, V. - Dajnoki, K. - Kerezsi, D. - Bácsné Bába, É. (2019): Analysis of Sport Motivation Factors amongst Eastern European Higher Education Students. European Journal Of Contemporary Education, Vol. 8. No. 4. 761-778. p. DOI: $10.13187 /$ ejced.2019.4.761

[35.] Fyodorov, A. I. - Erlikh, V. V. - Khafizova, A. - Bendikova, E. (2019): Young students' health attitudes. Journal of Physical Education and Sport, Vol. 19. No. 4. 2512-2517. p.

[36.] Gage, N. L. - Berliner, D. C. (1991): Educational Psychology. Boston, Houghton Mifflin Company.

[37.] Gődény N. - Biró M. - Lenténé P. A. - Lente L. - Müller A. (2018): A fogyasztói szokások és trendek változásának vizsgálata a fitnesz területén. In Balogh L. (szerk.) Fókuszban az egészség. Debrecen, Debreceni Egyetem Sporttudományi Koordonációs Intézet, 9-18. o.

[38.] Gősi Zs. - Boros, Sz. - Patakiné Bősze J. (szerk.) (2019): Sokszínű rekreáció: Tanulmányok a rekreáció témaköréből. Budapest, Eötvös Loránd Tudományegyetem Pedagógiai és Pszichológiai Kar, 140 o.

[39.] Héder, M. - Szabó, Sz. - Dajnoki, K. (2018): Effect of Labour Market Changes on HR Functions. The Annals of the Faculty of Economics Subotica, Vol. 54. No. 39. 123-138. p. DOI: $10.5937 /$ AnEkSub1839123H

[40.] Herpainé L, J. (2018): Three generation research concerning sport and value. In: Šimonek, J. - Dobay, B. (Eds.) Sport science in motion: Proceedings from the scientific conference. Komárno, Univerzita J. Selyeho, 274-280. p.

[41.] Hidvégi P. - Bíró M. - Müller A. - Váczi P. (2017): Testnevelési program a munkahelyi egészségfejlesztésben. Acta Academiae Paedagogicae Agriensis Nova Series: Sectio Sport, Vol. 44. 115-138. o.

[42.] Horkay, B. - Lenténé Puskás, A. - Biró, M. (2018a): The supply elements and the recreational possibilities in the city and in the countryside In: Šimonek, J. - Dobay, B. (Eds.) Sport science in motion: proceedings from the scientific conference. Komárno, Univerzita J. Selyeho, 330-339. p.

[43.] Horkay B. - Lenténé Puskás, A. - Bíró M. (2018b): A város és vidék kínálati elemeinek és szabadidős lehetőségeinek összehasonlítása egy vizsgálat tükrében. In: Balogh L. (szerk.) Fókuszban az egészség. Debrecen, Debreceni Egyetem Sporttudományi Koordinációs Intézet, 9-105. p.

[44.] Iski G. - Rurik I. (2014): Becslések a túlsúly és az elhízás hazai gazdasági ter-heiről [The Estimated Economic Burden of Overweight and Obesity in 
Hungary]. Orvosi Hetilap. 155. évf. 35. sz. 1406-1412. o. DOI: 10.1556/OH.2014.29902

[45.] Józsa K. (2007): Az elsajátítási motiváció. Budapest, Műszaki Kiadó.

[46.] Juhász I. - Kopkáné Plachy J. - Kiszela K. - Bíró M. - Müller A. - Révész L. (2015): Időskorúak rekreációs fizikai aktivitásának hatása a kardiorespiratorikus rendszerre. Magyar Sporttudományi Szemle 16. évf. 63. sz. 4-8. o.

[47.] Kith, N. - Csernoch, L. - Balatoni, I. (2014): Sport habits in North-Eastern Hungary. J Health Sci, Vol. 4. No. 13. 46-59. p.

[48.] Kosztin N. - Balatoni I. (2020): Kisgyermekes édesanyák sportolási szokásai. Acta Medicinae et Sociologica, Vol. 11. 88-98. o.

[49.] Kibédi Z. - Hideg G (2019): Változó világ, változó szerepek. Sztárok, celebek, média és hatásuk a családalapítási szokásokra. In: Juhász E. - Endrődy O. (szerk.) Oktatás-Gazdaság-Társadalom. Budapest; Debrecen, Debreceni Egyetem; Magyar Nevelés- és Oktatáskutatók Egyesülete (HERA), Paper: 423.

[50.] Kerényi E. - Müller A. - Könyves E. - Lázárné Fodor I. - Mosonyi A. (2010): Turisztikai márka és termékfejlesztés lehetőségei az egészségturizmusban az Észak-magyarországi és az Észak-alföldi régiókban. Acta Academiae Agriensis. 30. évf. 7. sz. 67-73. o.

[51.] König-Görögh D. - Szerdahelyi Z. - Czimbalmos-Laoues N. - Olvasztőóné Balogh, Zs. (2019): 4-6 éves korú magyar óvodások testi fejlődésének és motorikus szintjének összehasonlító elemzése. In: Pálfi S. (szerk.) Kora gyermekkori nevelés, család és közösségek = Early childhood education, families and communities: A Debreceni Egyetem Gyermeknevelési és Gyógypedagógiai Kara által szervezett EECERA 2018 Konferencia. Debrecen, Didakt Kft., 95-107. o.

[52.] Könyves E. - Müller A. - Mondok A.: Az egészségturizmus lehetőségei Hajdúszoboszló példáján. Szolnoki Tudományos Közlemények, Vol. 8. 11 p.

[53.] Központi Statisztikai Hivatal (2016)

[54.] Laoues-Czimbalmos N. - Müller A. - Bácsné B. É. (2019): Comparative analysis of active and passive recreational consumption habits of disabled children living in the Northern Great Plain region. Különleges Bánásmód, 5. évf. 1. sz. 31-39. DOI: 10.18458/KB.2019.1.31

[55.] Laoues- Czimbalmos, N. - Dobay, B. - Müller, A. (2019): Examination of the Leisure Time-Related Consumption Habits of Young People With Disabilities with Special Emphasis on Sports, Selye E-Studies, Vol. 10. No. 2. 34-45. p.

[56.] Laoues-Czimbalmos N. - Bába É. - Szerdahelyi Z. - Müller, A. (2019): Sportmotivációs tényezők vizsgálata a 8-18 éves fogyatékossággal élő 
korosztály körében. Acta Carolus Robertus, 9. évf. 1. sz. 121-132. o. DOI: 10.33032/acr.2019.9.1.121

[57.] Lengyel A. (2015): Magyarország egészségturisztikai desztinációként való márkázása: aszinkronitási problémák. Economica (Szolnok), 8. évf. 1. sz. 68-73. o.

[58.] Lengyel, A. (2016): Tourism, meditation, sustainability. Apstract - Applied Studies In Agribusiness and Commerce, Vol. 10. No. 1. 81-92. p. DOI: 10.19041/apstract/2016/1/11

[59.] Lengyel, A. (2019). A mindfulness és liminalitás felértékelődése: spirituális elvonulási központok, a fenntartható jövő desztinációi? Turizmus Bulletin, 19. évf. 1. sz. 14-24. o.

[60.] Lenténé Puskás, A. - Bíró, M. - Hidvégi, P. - Molnár, A. - Lente, L. Pucsok, J. (2019a): Analysis of the North Great Plain Region's Accommodation Supply with Special Focus on Sport and Wellness Elements. Geosport For Society, Vol. 10. No. 1. 15-24. Paper: /gss.1002-046

[61.] Lenténé Puskás, A. - Tatár A. - Lente L. - Pucsok J. - Bíró M. - Hidvégi P (2019b): A sport és wellness elemek megjelenése az Észak- alföldi régió három-, négy- és ötcsillagos szállodáinak kínálatában. In: Bácsné, B. É. Müller, A. (szerk.) „Mozgással az egészségért” A fizikai aktivitás jelentősége a jövő munkavállalóinak egészségmegőrzésében: Nemzetközi Konferencia és Workshop: Válogatott tanulmánykötet. Debrecen, Debreceni Egyetem, 204-215. o.

[62.] Lenténé Puskás, A. (2014): A párhuzamos karrierépítés lehetőségei élsportoló egyetemisták körében. Taylor: Gazdálkodás-és Szervezéstudományi Folyóirat: A virtuális Intézet Közép-Európa Kutatására Közleményei, 1-2. sz. 403-412.

[63.] Lenténé Puskás A. (2017): A sportolói karrier és a tanulmányok összehangolásának lehetőségei és kihívásai a Debreceni Egyetemen. [Doktori Disszertáció].

[64.] Lövei-Kalmár K. (2017): A fürdők jelentősége az Észak-Alföldi régióegészségturizmusának fejlesztésében, Köztes-Európa Társadalomtudományi folyóirat : A Virtuális Intézet Közép-Európa Kutatására Közleményei, 9. évf. 1-2. sz. / No. 21-22. 205-214. o.

[65.] Magyar M. (2018): Nyári időszakban rejlő animációs lehetőségek. Recreation, Vol. 8. No. 2. 16-17.o.

[66.] Mező F. - Mező K. (2017): A szülők nevelési stílusa és hatásuk a gyermekek magatartására: a családból való kimenekülés pedagógiai okai. In: Vargáné Nagy A. (szerk.) Családi nevelés 2. Debrecen, Didakt Kft., 50-66.

[67.] Mosonyi A. - Könyves E. - Fodor I. - Müller A. (2013): Leisure activities and travel habits of College students in the light of a survey. APSTRACT - 
Applied Studies In Agribusiness And Commerce, Vol. 7. No. 1. 57-61. p. DOI: $10.19041 /$ apstract/2013/1/10

[68.] Molnár A (2019): Fitnesz trendek az egészség szolgálatában. In: Bácsné Bába É. - Müller A. (szerk.) „Mozgással az egészségért” A fizikai aktivitás jelentősége a jövő munkavállalóinak egészségmegőrzésében : Nemzetközi Konferencia és Workshop : Válogatott tanulmánykötet. Debrecen, Debreceni Egyetem, 113-120. o.

[69.] Molnár Cs. - Kincses Á. - Tóth G. (2010): A fürdőfejlesztések hatásai Kelet-Magyarországon - Hajdúszoboszló, Mezőkövesd és Orosháza összehasonlítása. In: Turizmus Bulletin, 13. évf. 4. sz. 20-32. o.

[70.] Molnár A. (2019): Fitnesz trendek az egészség szolgálatában. In: Bácsné Bába É. - Müller A. (szerk.) „Mozgással az egészségért” A fizikai aktivitás jelentősége a jövő munkavállalóinak egészségmegőrzésében : Nemzetközi Konferencia és Workshop : Válogatott tanulmánykötet. Debrecen, Debreceni Egyetem, 113-120. o

[71.] Mosonyi, A. - Lengyel, A. - Müller, A. (2013): Brandingpotential of spasintheNorthernPlain and theMid-TransdanubianRegions. In. Apstract, Vol. 7. No. 4-5. 97-100. p. DOI: 10.19041/APSTRACT/2013/4-5/13

[72.] Mosonyi, A. - Könyves, E. - Fodor, I. - Müller, A. (2013): Leisure activities and travel habits of College students in the light of a survey. Apstract, Vol. 7. No. 1. 57-61. p. DOI: 10.19041/APSTRACT/2013/1/10

[73.] Murányi I. (2010). Egyetemisták szabadidős tevékenysége és mentális sátusa. Educatio, 2. sz. 203-213. o.

[74.] Müller A. (2018): Health tourism in Hungary. In: Šimonek, J.- Dobay B. (szerk.) Sport Science in Motion : Proceedings from the scientific conference. Komárno, Univerzita J. Selyeho, 8-15. p.

[75.] Müller A. - Barcsák B. - Boda E. (2016): Health tourism the cavebath of Miskolctapolca. In: Juhász Gy. - Korcsmáros E. - Huszárik E. (szerk.) Korszerủ szemlélet a tudományban és az oktatásban. Gazdaságtudományi szekció: Zborník medzinárodnej vedeckej konferencie Univerzity J. Selyeho 2016 „Súcasné aspekty vedy a vzdelávania". Sekcie ekonomických vied Komárno, Selye János Egyetem, 233-245. o.

[76.] Müller A. - Seres J. - Széles-Kovács Gy. - Kristonné Bakos M. -Váczi P. (2010): Az animátorok szerepe az egészségturizmus területén. In: Acta Academiae Agriensis, 30. évf. 7. sz. 75-86. o.

[77.] Müller A. - Kórik V. (2009): Az Észak-alföldi fürdők szerepe a turizmusban és a rekreációban. In. Economica, 2. sz. 58-72. o.

[78.] Müller A. - Könyves E.: Az egészségturizmus lehetőségei az Észak-alföldi régióban. Acta Academiae Paedagogicae Agriensis Nova Series: Sectio Sport, Vol. 33. 132-143. o. 
[79.] Müller A. - Bácsné Bába É. (2018): Az egészséges életmód és a sport kapcsolata. Létavértes, Létavértes SC '97 Egyesület, 96 o.

[80.] Müller A. - Lengyel A. - Koroknay Zs. - Molnár A. (2019b): Népszerü fitnesz mozgásformák. In: Bácsné Bába É. - Müller A. (szerk.) „Mozgással az egészségért" A fizikai aktivitás jelentősége a jövő munkavállalóinak egészségmegőrzésében: Nemzetközi Konferencia és Workshop: Válogatott tanulmánykötet. Debrecen, Debreceni Egyetem, 106-112.

[81.] Müller, A. - Kerényi, E. - Könyves, E. (2011): Effect of climate therapy and rehabilitation in Mátra Medical Institute. Applied Studies in Agribusiness and Commerce, Apstract - Applied Studies In Agribusiness and Commerce, Vol. 5. No. 3-4 39-42. p. DOI: 10.19041/APSTRACT/2011/3-4/5

[82.] Nagy J. (2000). A XXI. század és nevelés. Annalsof the University of Oradea Economic Science, 24. évf. 2. sz. 506-514. o.

[83.] Petruzzello, S. J. - Landers, D. M. - Hatfield, B. D. - Kubitz, K. A. - Salazar, W. (1991): A metaanalysis on the anxiety-reducing effects of acute and chronic exercise: outcomes and mechanisms. Sports Medicine, No. 11. 143-182. DOI: $\underline{10.2165 / 00007256-199111030-00002}$

[84.] Pluhár, Zs. - Keresztes, N. - Pikó, B. (2003): A rendszeres fizikai aktivitás és a pszichoszomatikus tünetek kapcsolata általános iskolások körében. Sportorvosi Szemle, 4. sz. 43-47.

[85.] Salbe, A. D. - Weyer, C. - Harper, I. (2002): Assessing risk factors for obesity between childhood and adolescence II.: Energy metabolism and physical activity. Pediatrics, No. 110. 307-314. DOI: 10.1542/peds.110.2.307

[86.] Simon I. Á. - Kajtár G. - Herpainé Lakó J. - Müller A. (2018): A fizikai aktivitás és a mentális egészség jelentősége a 60 év fölötti korosztály életében. Képzés És Gyakorlat, 16. évf. 1. sz. 25-36. o. DOI: 10.17165/TP.2018.1.3

[87.] Twisk, J. W. R. - Kemper, H. C. G. - Van Mechelen, W. (2002): Prediction of cardiovascular disease risk factors later in life by physical activity and physical fitness in youth: general comments and conclusions. International Journal of Sports Medicine, No. 23. 44-50. p. DOI: 10.1055/s-2002-28461

[I1] Eurostat. Practising sport, fitnessorrecreational (leisure) physicalactivitiesatleastonce a week, by sex. Statisticson sport participation. https://ec.europa.eu/eurostat/statistics-explained/index.php?title=Statistics_on_sport_participation\#Active_participation_in_s port) (2018)

[I2] Special Eurobarométer 2017. file:///C:/Users/EKF/Downloads/ebs_472_en.pdf 


\section{Szerzők:}

Kinczel Antonia

BSC-hallgató

I. évfolyam

Debreceni Egyetem

antokincz@gmail.com

Laoues-Czimbalmos Nóra

tanársegéd

Debreceni Egyetem, GYGYK

laoues.nora@ped.unideb.hu

\section{Dr. Müller Anetta}

egyetemi docens

Debreceni Egyetem, GTK

muller.anetta@econ.unideb.hu 